\title{
Discussion Management of Math Subject Teacher to Increase The Ability of High School Teachers In The Implementation of The 2013 Curriculum in Banda Aceh
}

\author{
Muslia $^{1}$, Cut Zahri Harun ${ }^{2}$, Sakdiah Ibrahim $^{3}$ \\ ${ }^{1}$ Master Of Education Administration Postgraduate Program in Syiah Kuala University Banda \\ Aceh \\ 2,3 the education administration master's program at the University of Syiah Kuala, \\ Darussalam, Banda Aceh 23111, Indonesia \\ \{muslia766@gmail.com\}
}

\begin{abstract}
The management of a group discussion of the mathematics subject teachers is very important to increase the ability of high school teachers in the implementation of the 2013 curriculum so that education quality of the senior high school in the Aceh which is directly a part of Aceh Education Department Office is increasing every year. This study aims to understand the design, the implementation, the use of funds and the monitoring system to the group discussion of match subject teachers in increasing the capacity of a high school teacher upward. This research used the qualitative technique data collection by doing interview, documentation, and observation. This research was carried out at the group discussion of math-subject teachers in Banda Aceh. The subject of study is the head of the group and also teachers who are active in the group. The research results show that the planning program activities to increase the capability of teachers senior high school has already been good, such as in making and setting some programs that have been planned to enhance the capacity of a high school teacher in implementing the curriculum 2013 in Banda Aceh. The activities include :(1) Designing and making a relevant, innovative and creative lesson plan, (2) Designing and making innovative teaching materials, (3) Designing and making proper assessment and (4) Discussing the test that considered as the hard ones (including teacher competency test). The implementation of the group discussion of math teacher runs well, nevertheless some participants are absent in the activities. The fund used for these activities is from the national and regional budgets in accordance with guidance and directions of the Aceh Education Department. The Supervisor System is done in two ways; direct and indirect ways. The direct supervisory system allows the superintendent to attend directly ceremonial events. While Indirectly supervisor system is used by making the written report of the activity. No evaluation is done whether to the activities and the program itself.
\end{abstract}

Keywords: A group discussion of math teacher management, the ability of high school teachers, and the 2013 curriculum. 


\section{Introduction}

Throughout human history, there have been records of a variety of regular and systematic behaviors, this is because Allah SWT after creating human and nature and its contents provides rules through angels and his prophets. Furthermore, the process of inheriting value by one generation to the next generation is done through social interaction and socialization among them, both formal, non-formal and informal. Socialization behavior is formally named as education and teaching behavior, even it becomes very important for a nation, so education is arranged in such a way as to shape behaviors that characterize and become the personality of the nation's generation continuously.

The 1945 constitution of Republic Indonesia mandates Pancasila as the basis of the nation and view of the nation's development. One of the aspects of development is education. Development in education is very important considering the function of education is as a process of forming the character of the nation both philosophy, ideology, normative, historic and socialcultural. The implementation of the mandate of the constitution was outlined in the 2003 national education system law which confirmed that:

Education is a conscious and planned effort to create a learning atmosphere, and learning process so that students actively develop their potential to have religious spiritual strength, selfcontrol, personality, intelligence, noble character, and skills needed by themselves, society, and nation.

Education that leads to the development of the nation's character is a big idea that was sparked by the founder of the nation because it is very important for a pluralistic Indonesian society to realize the welfare and prosperity of all the people of Indonesia. National development that has been carried out has shown progress in various fields of life, but development in the old education still has a lot of problems and challenges that have not been fully resolved.

Education is an absolute and important activity for human life, with human education know himself, the creator and the surrounding environment. With human education can recognize manners, good bad, right wrong, beautifully ugly, which is concluded as values and norms, and laws to other people in certain ways both formal, informal and non-formal.

World civilization demands human resources who are strong, competent, have the motivation and work experience who are skilled in carrying out their roles and functions both for individuals and organizational goals. Teachers as educational institutional implementers objectives built by the central government and regional governments at the provincial and district/city levels are of course always improving and developing themselves.

According to Low no.14 of 2005 article 1 am concerning, teachers and lectures, especially teachers are professional educators with the main task of educating, teaching, guiding, directing, training, assessing, and evaluating students in early childhood education through formal education, basic education, and secondary education. Meanwhile, educators are professional educators and scientists with the main task of transforming, developing, and disseminating science, technology, and art through education, research, and community service. With the emergence of this law teachers/lectures have been recognized as professionals equivalent to other professions. What is meant by professionals here is work or activity carried out by a person and becomes a source of live income that requires expertise, skills, or skills that meet certain quality standards or norms and require professional education.

The teaching profession has the main task of serving the community in the world of education to achieve the goals of national education to improve the quality of education today, the professionalization of teachers is intended to stimulate, maintain, and improve teacher 
competencies in solving education and learning problems that have an impact on improving the quality of student learning outcomes.

Depdiknas sets 14 activities in the context of developing teacher competencies, including programs to improve teacher education qualifications, equalization and certification programs, competency-based integrated equalization programs, education supervision programs, and empowerment program of discussion of the subject teacher. We are all increasingly aware of the strategic existence of subject matter discussions on increasing the quality of education in Indonesia.

The main thing in this research is the group discussion of math teacher management to increase the ability of high school teachers in the implementation of the 2013 curriculum. From the main things, there are four things that are done in the research, include:

The programs planned for the group discussion of math teacher meetings to increase the ability of high school teachers in the implementation of the 2013 curriculum

The implementation of the group discussion of math teacher to increase the ability of high school teachers in the implementation of 2013

Management of the group discussion of math subject teacher to increase the ability of high school teachers in the implementation of 2013

The monitoring system of the group discussion of math teacher to increase the ability of high school teachers in the implementation of 2013.

as for the purpose of this research include :

To be able to explain the programs planned in the meeting the group discussion of math teacher to increase the ability of high school teachers in the implementation of the 2013 curriculum

The explaining about the implementation of the group discussion of math teacher to increase the ability of high school teachers in the implementation of the 2013 curriculum.

To explain about fund management the group discussion of math teacher to increase the ability of high school teachers in the implementation of the 2013 curriculum

To explain the supervisory system of the group discussion of math teacher to increase the ability of high school teachers in the implementation of the 2013 curriculum.

At present, it is a very good momentum if the teacher, Indonesian republican teacher association, local government, regional legislative council, education quality assurance institution, education and culture department, and related parties carry out a joint movement to empower the discussion of a math teacher. We are all increasingly aware of the strategic existence of subject matter deliberations on increasing the quality of education in Indonesia. Real steps that can be taken so that the group discussion of the teacher is empowered as follows:

Operational funding assistance for subject teachers from the regional government and central government must be further enlarged, along with $20 \%$ of funds allocated for education from the central government.

The role of the group discussion of math teacher in developing teacher professionalism is even more important after the government enacts a new curriculum.

By promoting the group discussion of teachers as a place for teachers to reform themselves in order to be able to prepare students who are strong, creative, critical, and skilled, it is expected that the learning process approach is no longer teacher-centered but student-centered. Various learning innovations such as contextual learning (Contextual Teaching and Learning), CBSA (Student Active Learning), Problem Solving (Problem-Based Learning), and so on are expected to be mastered by the teacher well.

But in reality, there are still teachers who have not utilized it the discussion of subject teacher increase their professionalism by participating in various activities both at the school level, at 
the city/district level, and at the provincial level. In addition, the awareness and commitment of some of the management towards their responsibilities in the organization still need to be improved. Even though the funds carry out the work program are sufficient, both block grand funds from the state budget and expenditure and from the regional income and expenditure budget. Another obstacle faced by the discussion of a math teacher is that the training provided by competent parties is lacking. Therefore, the writer is very interested in wanting to examine the title of: "discussion of management mathematics subject teacher to improve the ability of high school teachers in the 2013 Curriculum Implementation in Banda Aceh.

\section{Literature review}

Fajri [1] that management is "Effective use of resources to achieve the intended goals or objectives". several management functions namely; planning, organizing, actuating, financing (budgeting), and controlling (controlling).

\subsection{Teachers as Educational Resources}

Educators and education personnel are all people who carry out the education process. Those who are classed as educators and education personnel are called human resources education. The competence of teachers is covering; pedagogic competence, personality competence, social competence, and professional competence.

\subsection{The aim of developing teacher professionalism}

The purpose of teacher development through teacher development is to improve the teaching and learning process in which teachers and students are involved, through a series of actions, guidance, and direction. Furthermore, as a tribute to teachers who are able to improve their professional quality, they are given awards, including by increasing their rank/class.

\subsection{Purpose teacher professional development}

The purpose of teacher development through teacher coaching is to increase of teacher competence is carried out through various strategies in the form of both education and training (diklat) and non-education and training. As for education and training can be explained as follows:

1. Education and training.
a. In house training (IHT).
b. Internship program.
c. School partnership.
d. Tiered training and special training.
e. Internal coaching by the school.
f. Further education.

2. A Group Discussion of Teacher as Self- Development Containers

Discussion Of Subject Teacher a forum/forum for professional activities subject teachers of a kind of deliberation reflect activities from, by, and for teachers. What is meant by subject teachers are junior high school/MTs and high school/MA teachers, who take care of and are responsible for managing the subjects specified in the curriculum 


\section{Discussion and Result}

\subsection{Activity Program of Group Discussion of Math Teacher in Banda Aceh}

The Group Discussion Of Math Teacher held socialization of the 2013 Curriculum Implementation. This was in accordance with the mandate of the government through the directorate general who carried out the socialization and training to the core teachers. The teacher teaches information gathered in Jakarta to all of his friends from the Discussion of math subject. Therefore the Discussion of Subject Math Teacher has helped the government in achieving its goals in the field of education to implement the national curriculum. Discussion of the subject teacher becomes the government's hand in the implementation and success of the national curriculum, namely the 2013 curriculum.

Ahead of the implementation of the activity, the management prepared a place, office stationery, prepared a schedule of events, prepared necessary infrastructure such as wireless, overhead projectors and informed participants and invited resource persons and related parties.

\subsection{Activity Implementation Of Discussion Of Math Subject Teacher}

Discussion Of Subject Math Teacher carry out activities that are in accordance with the needs of the teacher namely; "Updating information, especially about the latest government policies so that teachers can always prepare themselves in teaching according to curriculum expectations". Discussion Of Subject Math Teacher Banda Aceh City facilitates Mathematics teachers in the city of Banda Aceh to improve their competence in the implementation of the 2013 curriculum. Acting as facilitators in these activities include widyaiswara from the Aceh Educational Quality Assurance Institute, lecturers of Syiah Kuala University and Ar Raniry Islamic University and resource person or instructor for National Mathematics.

\subsection{Fund Management}

Sources of funds for the implementation of Group Discussion Of Math Teacher activities come from the central government (the state budget and income) which is called the Block grand fund and from the Banda Aceh Education Agency called operational funds. Before the activity is carried out the management has prepared a budget plan and submitted it to the government.

The Group Discussion Of Math Teacher proactively proposes funds to the government for math teachers in Banda Aceh so that they can improve their competence in the implementation of the 2013 curriculum.

\subsection{Monitoring System}

The supervisory system of the Discussion Of Subject Math Teacher was carried out by supervisors from the Aceh Education Office who carried out their duties to conduct direct supervision by attending the opening of the event. There are those who open the activity directly or just attend it if the activity is opened by the head of the service. Indirect supervision is also carried out by asking for reports from the management for each activity. 


\section{Conclusions and Recommendations}

\subsection{Conclusions}

1. Management of The Group Discussion Of Math Teacher is arranged to plan program activities, among others; (1) Design and make learning tools that are relevant, innovative and creative, (2) Design and make innovative teaching materials, (3) Design and make a proper assessment system, and (4) Discuss questions that are considered difficult (including math teacher competency test).

2. The implementation of Mathematics Teacher Consultation activities, in general, can be carried out especially in terms of activities and material is sufficient, but the attendance of participants is not as optimal as the number of actual participants. The types of activities carried out are in accordance with the needs of teachers and schools.

3. Management of Discussion Of Subject Math Teacher funds in accordance with the instructions and direction of the supervisor and Education Office of Banda Aceh City in the previous period and the Aceh Provincial Education Service to improve the ability of high school teachers in the implementation of the 2013 Curriculum

4. There is a direct and some indirect monitoring system for The Group Discussion Of Math Teacher. Directly, supervisors attended the ceremonial event directly opening MGMP activities. Indirectly through the report of the committee or committee in writing. There is no evaluation action, and follow-up is planned by the organization's management

\subsection{Recommendations}

1. With the planning expected, the Management of The Group Discussion Of Math Teacher in the future will be better with excellent programs that are useful for improving the competence of high school math teachers.

2. With the implementation of Discussion The Group Discussion Of Subject Math Teacher, the government is expected that the Education Office can increase attention to the teacher organization, namely the Discussion Of Subject Math Teacher, and the mathematics teacher must utilize the Discussion Of Subject Math Teacher as a self-development forum.

3. With the management of The Group Discussion Of Math Teacher in accordance with the instructions and direction of the supervisor and the Office of Education, it is expected to improve the ability of high school teachers in the implementation of the 2013 Curriculum

4. Through the proper supervision system, it is expected that the management can conduct an evaluation, and follow up on the MGMP organization that is its responsibility so that the behavior of the teacher organization is more effective

\section{REFERENCE}

[1] Departemen Pendidikan Indonesia, Kamus besar Bahasa Indonesia. Jakarta: Balai Pustaka, 2008. 